\title{
Histological Effects of Cystic Echinococcosis on the Liver of Sheep
}

\author{
Nabeel Zaki Zahed \\ Department of Biological Science, Faculty of Science, King Abdul Aziz University, \\ Kingdom of Saudi Arabia
}

\begin{abstract}
:
Aim of the work: The author investigated the histological effects of hydatid cyst (echinococcosis) on the liver of sheep.

Material and methods: This study was based on liver specimens of slaughtered sheep (twelve of infected and four of uninfected). Specimens were collected from abattoirs at Central Slaughterhouse area KSA. These specimens were investigated for the presence of hydatid cyst and then examined histologically for identification of the histopathological changes.

Results: The infection with cystic echinococcosis induced significant elevation $(\mathrm{P} \leq 0.05)$ in the hepatosomatic index of infected sheep. Hydatid cysts in the liver of sheep resulted in different histological lesions represented in inflammatory reaction, fibrosis and necrosis in the area near to the cysts. Meanwhile the hepatocytes exhibited vacuolated cytoplasm and dilated blood vessels and disintegration in the epithelia of the bile duct.
\end{abstract}

Key words: Sheep, Liver, Hydatid cyst, Histology.

\section{Introduction:}

Hydatid disease due to cystic echinococcosis is one of the most important public health and economic problems in different countries including Saudia Arabia. Hydatid disease is a zoonosis caused by the tapeworm of Echinococcus spp. These species include $E$. granulosus, $E$ multilocularis, $E$ vogeli or $E$ oligarthrus (Lewis et al., 1975). These parasites live as a small intestinal tapeworm of dogs and occasionally other carnivores (Dent and Kelly, 1976). Their larval form causes hydatidosis in domestic animals and man (Baldock et al., 1985). The shedding of gravid proglottids or eggs in the feces occurs within 4-6 weeks after infection of the definitive host. Ingestion of eggs by intermediate host animals (sheep, cattle, goats, horses, camels) or human results in the release of an oncosphere into the gastrointestinal tract, which then migrates to primary target organs such as liver and lungs, and less frequently to other organs (Amman and Eckert, 1996). Usually the fully mature metacestode (i.e. hydatid cyst) develops within several months or years. The hydatid disease is prevalence where livestock is raised in association with dogs. Those endemic areas include Australia, Latin America, Europe, Africa and the
Middle East (Schaefer JW and Khan, 1991).

Liver is the most common site of cystic development, in over $90 \%$ of liver cysts; the oncosphere is trapped in the central veins of the hepatic lobules and the resultant cyst may be deep or superficial and it causes compression of the liver cells which can lead to biliary stasis and cholangitis (Kebede et al., 2009). The cyst may present as a liver abscess and large cyst can produce localized or diffuse hepatomegaly (Moro et al., 2000). Local pathological effects depend on the site of the hydaid cyst; ruptured liver cyst through the diaphragm can produce a pleural effusion or bronchobiliary fistula (Gerazounis et al., 2002).

The parasite destroys the liver parenchyma, bile ducts and blood vessels resulting in symptoms of biliary obstruction, portal hypertension and necrosis of the central portion of the cyst with abscess formation. Growth of the germinal membrane into blood vessels produces metastasis to almost any organ, but they are more commonly found in the lungs and brain (Gutierrez, 1990). 


\section{Materials and Methods:}

Liver samples of slaughtered ovine animals were collected from abattoirs at Central Slaughterhouse area KSA. The samples were investigated for the presence of the hydatid cysts, twelve of infected and four of uninfected liver were used in this study to identify the histological changes induced due to echinococcosis. Livers of infected and uninfected animals were weighted and photographed. The animal's body weights were obtained and the liver relative body weight (hepatosomatic index) was calculated according to the equation of Chellappa et al. (1995) as follows:

"Liver relative body weight $=$ (wt. of liver in gm. / wt. of animal gm). $X$ $\underline{100^{\prime \prime}}$

For histological examination, tissue samples from the infected and uninfected livers were fixed in $10 \%$ neutral formalin solution for 48 hours. Fixed tissues were carefully washed with water; dehydrated through a graded series of alcohol; cleared with xylene and embedded in paraffin wax. Sectioned at $5 \mu$ thick were made, mounted on glass slides and stained with hematoxylin and eosin (Humason, 1979). For measurement of the hepatocytes activity, the nuclo-cytoplasmic index $\left(\mathrm{V}_{\mathrm{n}} / \mathrm{V}_{\mathrm{c}}\right)$, relative nucleolus volume $\left(\mathrm{V}_{\mathrm{no}} / \mathrm{V}_{\mathrm{n}}\right)$ and cytoplasmic optical density $\left(\mathrm{I}_{\mathrm{D}} / \mathrm{V}_{\mathrm{c}}\right)$ were calculated according to Ostaszewska et al. (2005). Where: $\mathrm{V}_{\mathrm{n}}=$ nuclear volume, $\mathrm{V}_{\mathrm{c}}=$ cytoplasm volume, $\mathrm{V}_{\mathrm{no}}=$ nucleolar volume and $\mathrm{I}_{\mathrm{D}}=$ cytoplasm optic density. Cell measurements were done using microscope Nikon-Alphaphot-2YS2, digital camera Nikon and computer image analysis system. The data obtained were statistically analyzed; differences between the group means were assessed using t-test; $\mathrm{P} \leq 0.05$ was considered significant. Cell measurements were done using the microscope Nikon-Alphaphot-2YS2, digital camera Nikon and computer image analysis system.

\section{Results}

The morphological results showed that the Echinococcus cysts were found either deep or superficial in the liver of sheep (Figs. 1 $\&$ 2). The infection with cystic echinococcosis induced significant elevation $(\mathrm{P} \leq 0.05)$ in the hepatosomatic index of infected sheep as compared with the uninfected ones. The percentage of elevation in this index was $10.63 \%$ (Table $1)$.

Histologically, the normal structures of the liver of uninfected sheep are illustrated (Fig. $3 \& 4$ ). The hepatic lobule contains a central vein from which radiate anatomizing and branching cords of hepatic cells. The hepatocytes are polyhedral in shape and enclosing a homogeneously fine granulated acidophilic cytoplasm and embodying a centrally placed large spherical nucleus, a prominent nucleolus and distinct chromatin particles.

The cysts discharged its fluid and leaving remaining of the sac after sections processing and exhibited a thick fibrous layer around it (Fig. 5). The hepatic lesions observed in hydatid cyst infected sheep liver were characterized by vacuolation in the cytoplasm of the hepatocytes, invasion of the Kupffer cells and proliferation of the inflammatory cells in and around the bile duct that replaced normal hepatocytes (Fig. 6). Moreover, obvious necrotic area in the liver of infected sheep was noticed around the cyst (Fig. 7). Also, dilated blood vessels, infiltration of eosinophiles and neutrophils and disintegration in the epithelial bile duct were noticed in sheep liver infected with hydatid cyst (Fig. 8).

Also, some hepatocytes showed pyknotized nuclei which appeared shrinked and condensed as single, round globules of uniformly intense, basophilic masses. Karyorrhexised nuclei showed disintegration of the chromatin into several deeply stained fragments. Karyolysed nuclei appeared as empty vesicles which disintegrate and disappear in the parenchyma around the cyst.

The nucleo-cytoplasmic index of the hepatocytes of hydatid cyst infected liver sheep showed a significant increase $(\mathrm{P} \leq 0.05)$ as compared with uninfected animals, the percentage of increment reached $357.47 \%$ (Table 2). The relative nucleolus volume of the hepatocytes in hydatid cyst infected animals showed insignificant decrease as compared with the 
uninfected; the percentage of decrement was $16.75 \%$ (Table 3 ). The cytoplasmic optical density of the hepatocytes showed significant decrease $(\mathrm{P} \leq 0.05)$ in infected animal in comparison with the normal ones. The percentage of decrement was $39.38 \%$ (Table 4).

\section{Discussion:}

The disease caused mainly by Echinococcus granulosus and E. alveolaris, especially by the larval stages of these cestode (tapeworm) species, is called echinococcosis (hydatid cyst). It may manifest as single or multiple cystic structures in various organs, predominantly in the liver (Maegraith, 1989; Gutierrez, 1990; Cotran et al., 1999 and Craig and Rogan, 2003). In accordance, the present study showed that the cysts of Echinococcus spp. were found either deep or superficial in the liver of sheep and most of them were found near the portal area. Tappe et al. (2007) reported that Echinococcus granulosius is endemic in area where wild baboons live and many mammal species, including humans, can become intermediate hosts by accidental ingestion of eggs deposited with feces.

The present study showed that the hepatosomatic index was significantly elevated in infected sheep which may be denoting active metabolic activity in these animals. In contrast, Kurtz et al. (2004) reported that tapeworm infection caused reduction in the hepatosomatic index. Whoever, Hammerschmidt and Kurtz (2005) reported that increase of the hepatosomatic index is an indication of multiple infections with the parasites.

The most common sites of echinococcus cysts are the liver (60\% to $70 \%$ of patients), brain and lungs, but they may occur in other locations including the spleen, soft tissue, bone, breast, heart and spinal extradural space (Farmer et al., 1990). Sheep, the natural intermediate host for the parasite and the disease process in sheep closely resembles that seen in humans (Baldock $\boldsymbol{e t}$ $\boldsymbol{a l}$., 1985). The present study revealed that the presence of hydatid cysts in the liver of sheep resulted in different histological lesions represented in inflammatory reaction, fibrosis and necrosis in the area near to the cysts. Meanwhile the hepatocytes exhibited vacuolated cytoplasm and dilated blood vessels and disintegration in the epithelia of the bile duct were perceptive. Such of these effects were mostly documented in different animals infected with different species of Echinococcus (Serefettin et al., 2003; Dai et al., 2004 and Kebede et al., 2009).

In goat and sheep, Blanton et al. (1998) showed evidence of marked host cellular reaction consisting of infiltration of the adventitial layer with neutrophils, eosinophils, and plasma cells. In addition to this inflammatory infiltrate, the new space between the liver tissue and cyst wall contained disorganized fibroblasts and mesenchymal cells. In the most necrotic areas, the laminate layer could not be collected together with adherent liver tissue and the adventitial layer appeared completely degenerated and it was replaced by acute inflammatory cells. Also, Dai $\boldsymbol{e t}$ al. (2004) reported that inflammatory reaction to hepatic infection with Echinococcus multilocularis metacestode was included marked granulomatous inflammation with occasional multinucleated giant cells and marked fibrosis around parasitic cysts in mice. Moreover, Gottstein and Hemphill (1997) mentioned that infection with Echinococcus spp induced cellular immunity characterized by the development of an intrahepatic granuloma surrounding the parasitic tissue.

The cytopolasmic vacuolation observed in the liver cells as a result of hydatid cyst infection is probably attributed to in part to progressive hypoxia and partly fatty accumulation as liver cell degeneration (Bha-tavdekar et al., 1987). Also, Ritter (1987) suggested that the liver cell necrosis may be either due to progressive action of intracellular enzymes of the injured cells or to a metabolic disturbance and inhibition of synthesis needed of DNA and hence protein synthesis. In the same respect, Dutta et al. (1994) showed that the increase of Kupffer cells in the liver act as a defense mechanism or an active phagocytosis in response to foreign materials. 
In conclusion, echinococcosis is still an important health problem in Saudia Arabia that needs further study. The people traveling to endemic areas should be educated not to contact with wild animals. There is a need for a suitable eradication program, so that untethered dogs as well as foxes, which play an important role in the contagiousness of the disease in rural areas, can be eradicated as an infectious agent.

\section{References:}

1. Amman RW and Eckert J (1996): Cestodes: Echinococcus. Gastroenterol. Clin. North Am., 25:655-689.

2. Baldock FC, Thompson RA and Kumaratilake LM1 (1985): Strain identification of E. granulosus in determining origin of infection in a case of human hydatid disease in Australia. Trans. Roy. Soc. Trap. Med. Hyg., 79: 175-180.

3. Bha-tavdekar J, Aravinda B and Shah V (1987): Effect of stress oon nucleic acids and protein content of guinea pig, rat and mice. Ind. J. Exp. Biol., 15: 908-912.

4. Blanton R, Ernest M, Wachira T, Magambo K, Zeyhle E, and Schantz P (1998): Oxfendazole Treatment for Cystic Hydatid Disease in Naturally Infected Animals. Am. Soc. Microbiol., 42(3): 601-605.

5. Chellappa S, Huntingford FA, Strang RH and Thomson RY (1995): Condition factor and hepatosomatic index as estimates of energy status in male three- spined stickleback. Journal of Fish Biology, 47: 775-787.

6. Cotran RS, Kumar V and Collins T. (1999): Pathologic Basis of Disease. Sixth ed. Philadelphia: WB Saunders Company., 395-396.

7. Craig PS and Rogan MT (2003): CamposPonce M. Echinococcosis: disease, detection and transmission. Parasitology, 127 Suppl: S5-20.

8. Dai W, Waldvogel A, Slles-Lucas M, and Gottstein B (2004): Echinococcus multilocularis proliferation in mice and respective parasite 14-3-gene expression is mainly controlled by an $\alpha \beta++$ CD4 T-cellmediated immune response. Immunology, 112: 481-488.

9. Dent CR and Kelly JD (1976): Cestodes parasites of dog in central table land of New South Wales. Aust. Vet. J., 52: 386388 .

10. Dutta M, Munshi D and Roy P (1994): Changes in lymphatic system of catfish, Heteropneustes fossilis. Integ. Comp. Biol., 34(5): 50-53.
11. Farmer PM, Chatterley $\mathrm{S}$ and Spier $\mathrm{N}$ (1990): Echinococcal cyst of the liver. Diagnosis and surgical management. Ann. Clin. Lab. Sci., 20: 385.

12. Gerazounis M, Athanassiadi K, Metaxas E, Athanassiou M and Kalantzi N (2002): Bronchobiliary fistulae due to echinococcosis. Eur. J. Cardiothorac. Surg., 22: 306-308.

13. Gottstein B and Hemphill A (1997): Immunopathology of echinococcosis. Chem Immunol., 66: 177-208.

14. Gutierrez Y (1990): Diagnostic Pathology of Parasitic Infections with Clinical Correlations. Philadelphia: Lea and Febiger., 460-480.

15. Hammerschmidt K and Kurtz J (2005): Surface carbohydrate composition of a tapeworm in its consecutive intermediate hosts: Individual variation and fitness consequences. Int. J. Parasitol., 35: 14991507.

16. Humason, GL (1979): Animal Tissue Technique. $2^{\text {nd }}$ ed. Freeman, W. H. and Company; pp 661.

17. Kebede N, Mitiku A and Tilabun G (2009): Hydatidosis of slaughtered animals in Bahir Dar abattoir, northwestern Ethiopia. Trop. Anim. Health Prod., 41(1): 43-50.

18. Kurtz J, Kalbe M, Aeschlimam P, Haberli M, Wegner K, Reusch T and Milinski M (2004): Major histocompatibility complex diversity influences parasite resistance and innate immunity. Biol. Sci., 271: 197-204.

19. Lewis JW, Koss $\mathrm{N}$ and Kerstein MD (1975): A review of echinococcal disease. Ann. Sug., 181: 390-396.

20. Maegraith B (1989): Clinical Tropical Diseases. Ninth ed. Oxford: Blackwell Scientific Pub., 471-482.

21. Moro PL, Gonzalez AE and Gilman RH (2000): Cystic hydatid diseases. In: Hunter's Tropical Medicine and Emerging Infectious Disease, $8^{\text {th }}$ ed. (Stickland G. T.) W. E. Saunders Co. USA: 866-871.

22. Ostaszewska T, Dabrowski K, Palacios M, Olejniczak M and Wieczorek M (2005): Growth and morphological changes in the digestive tract of rainbow trout (Oncorhynchus mykiss) and pacu (Piaractus mesopotamicus) due to casein replacement with soybean proteins. Aquaculture, 245: 273-286.

23. Ritter E J (1987): Altered Biosynthesis. In: Handbook of Teratology. Vol.2 Plenum Press, New York.

24. Schaefer JW and Khan MY (1991): Echinococcosis (hydatid disease): lessons from experience with 59 patients. Rev. Infect. Dis., 13: 243 - 247. 
25. Serefettin M, Merih G, Tulay $C$ and Astarcioglu H (2003): The Pathology of Echinococcosis and the Current Echinococcosis Problem in Western Turkey (A Report of Pathologic Features in 80 Cases). Turk. J. Med. Sci., 33: 369-374.
26. Tappe D, Brehm K, Frosch M, Blankenburg A, Schrod A, Kaup F, and Mtz-Rensing M (2007): Echinococcus multilocularis Infection of Several Old World Monkey Species in a Breeding Enclosure. Am. J. Trop. Med. Hyg., 77(3): 504-506.

Table (1): The hepatosomatic index in normal and infected sheep.

\begin{tabular}{|c|c|c|c|c|c|c|}
\hline \multirow{2}{*}{} & \multicolumn{2}{|c|}{ Body weight } & \multicolumn{2}{c|}{ Liver weight } & \multicolumn{2}{c|}{ Index } \\
\cline { 2 - 7 } & Normal & Infected & Normal & Infected & Normal & Infected \\
\hline Average & 25.33333 & 25.86667 & 0.7575 & 0.838 & 2.988333 & 3.235 \\
\hline S.D & 1.032796 & 0.665332 & 0.039718 & 0.048748 & 0.061455 & 0.190237 \\
\hline Min. & 25 & 25 & 0.695 & 0.789 & 2.9 & 2.96 \\
\hline Max. & 27 & 26.8 & 0.8 & 0.89 & 3.07 & 3.5 \\
\hline t test & & 0.132383 & & 0.017956 & & 0.009562 \\
\hline Probability & & Non Sig & & Sig & & Sig \\
\hline \% of change & & 2.105263 & & 10.62706 & & 8.254322 \\
\hline
\end{tabular}

Table (2): The nucleo-cytoplasmic index of hepatocytes in normal and infected sheep.

\begin{tabular}{|c|c|c|c|c|c|c|c|c|}
\hline \multicolumn{5}{|c|}{ Normal } & \multicolumn{4}{|c|}{ Infected } \\
\hline & $\begin{array}{c}\text { V.cell } \\
\mu 3\end{array}$ & $\begin{array}{c}\mathrm{V} . \\
\text { nucleus } \\
\mu 3\end{array}$ & V.cyto. $\mu 3$ & $\begin{array}{c}\text { Vol. of } \\
\text { N/ Vol. } \\
\text { of } \\
\text { Cytoplas } \\
\text { m }\end{array}$ & $\begin{array}{c}\text { V.cell } \\
\mu 3\end{array}$ & $\begin{array}{c}\mathrm{V} . \\
\text { nucleus } \\
\mu 3\end{array}$ & $\begin{array}{c}\text { V.cyto. } \\
\mu 3\end{array}$ & $\begin{array}{l}\text { Vol. of N/ } \\
\text { Vol. of } \\
\text { Cytoplasm }\end{array}$ \\
\hline Average & $\begin{array}{c}10.76 \\
6\end{array}$ & 0.917 & 9.849 & 0.111 & 25.428 & 5.007 & 20.421 & 0.509 \\
\hline S.D. & 5.137 & 0.488 & 5.031 & 0.065 & 15.234 & 2.456 & 14.661 & 0.696 \\
\hline Min. & 2.425 & 0.227 & 2.197 & 0.039 & 10.626 & 1.822 & 3.163 & 0.104 \\
\hline Max. & $\begin{array}{c}19.50 \\
1\end{array}$ & 1.822 & 18.497 & 0.229 & 54.278 & 8.951 & 45.327 & 2.359 \\
\hline $\mathrm{t}$ test & & & & & 0.008 & 0.000 & 0.026 & 0.05 \\
\hline Probability & & & & & Sig. & Sig & Sig & Sig \\
\hline$\%$ of change & & & & & 136.185 & 446.02 & 107.338 & 357.467 \\
\hline
\end{tabular}

Table (3): The nucleolus volume in normal and infected sheep

\begin{tabular}{|c|c|c|c|c|c|c|}
\hline & \multicolumn{3}{|c|}{ Normal } & \multicolumn{3}{c|}{ Infected } \\
\hline & Vn & Vno & Vno/Vn & Vn & Vno & Vno/Vn \\
\hline Average & 0.9170 & 0.0713 & 0.0874 & 5.0070 & 0.3275 & 0.0728 \\
\hline S.D. & 0.4876 & 0.0452 & 0.0675 & 2.4564 & 0.1256 & 0.0229 \\
\hline Min. & 0.2277 & 0.0169 & 0.0270 & 1.8220 & 0.1716 & 0.0406 \\
\hline Max. & 1.8220 & 0.1399 & 0.2620 & 8.9510 & 0.6250 & 0.1093 \\
\hline t test & & & & 0.0005 & 0.0001 & 0.2655 \\
\hline Probability & & & & Sig & Sig & Non Sig \\
\hline \% of change & & & & 446.0188 & 359.4393 & -16.7504 \\
\hline
\end{tabular}

Table (4): The cytoplasmic optical density (ID/Vc) of hepatocytes in normal and infected sheeps.

\begin{tabular}{|c|c|c|c|c|c|c|}
\hline & \multicolumn{3}{|c|}{ Normal } & \multicolumn{3}{c|}{ Infected } \\
\hline & $\mathrm{Vc}$ & $\mathrm{ID}$ & $\mathrm{ID} / \mathrm{Vc}$ & $\mathrm{Vc}$ & $\mathrm{ID}$ & ID/Vc \\
\hline Average & 9.8493 & 84.2802 & 11.3775 & 20.4213 & 79.3543 & 6.8974 \\
\hline S.D. & 5.0312 & 23.0332 & 8.3901 & 14.6615 & 16.9502 & 5.9810 \\
\hline Min. & 2.1973 & 53.7200 & 4.6840 & 3.1629 & 48.5000 & 1.6155 \\
\hline Max. & 18.4675 & 126.2070 & 33.8000 & 45.3270 & 101.9430 & 20.3340 \\
\hline t test & & & & 0.0259 & 0.3391 & 0.0210 \\
\hline Probability & & & 660 & Sig & Non Sig & Sig \\
\hline \% of change & & & & 107.3384 & -5.845 & -39.376 \\
\hline
\end{tabular}



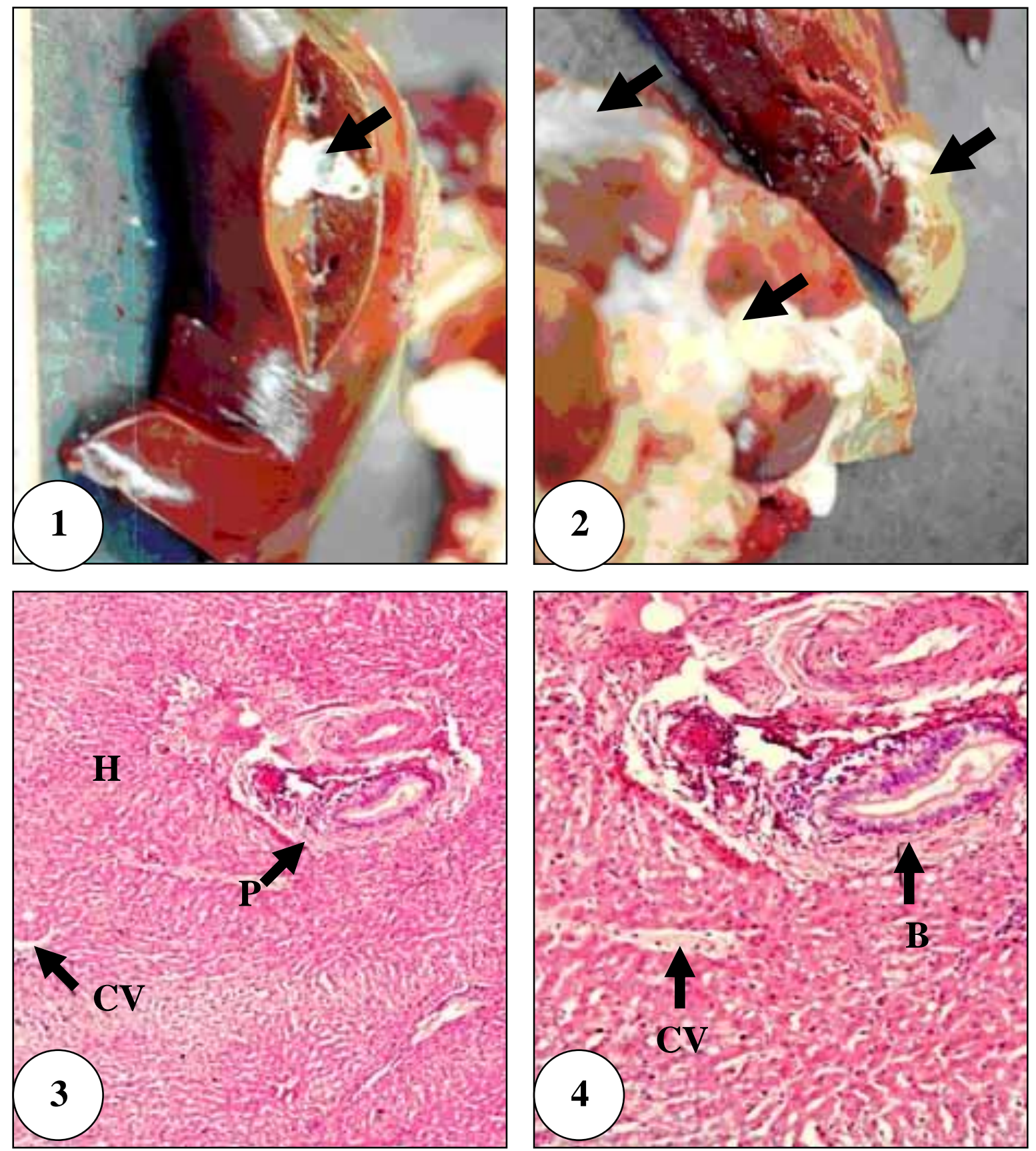

Fig. (1): Photographic picture of sheep liver showing deep infection with hydatid cyst (arrow).

Fig. (2): Photographic picture of sheep liver showing superficial infection with hydatid cyst (arrows).

Fig. (3): Liver section of normal sheep liver showing normal hepatocytes $(\mathrm{H})$, central vein (CV) and portal area (P). (H/E X 100).

Fig. (4): Liver section of normal sheep liver showing normal central vein (CV) and normal epithelia of the bile duct (B). (H/E X 200). 

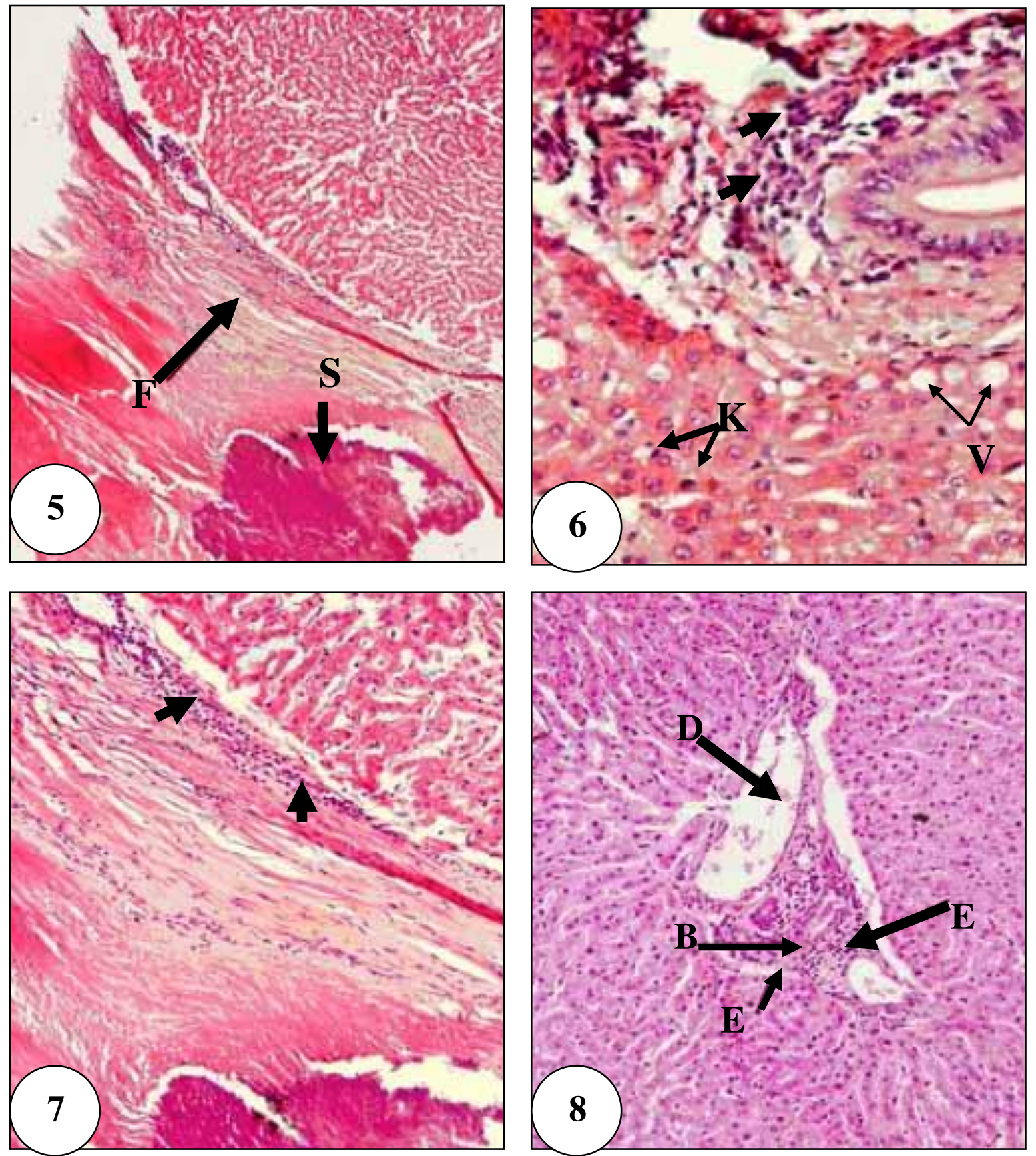

Fig. (5): Liver section of hydatid cyst infected sheep liver showing remaining of the sac after discharge of the fluid (S) and fibrous layer (F) around the parasitic sac. (H/E X 100).

Fig. (6): Liver section of hydatid cyst infected sheep liver showing vacuolated hepatocytes (V), inflammatory cells around bile duct (arrows) and invasion of Kupffer cells (K). (H/E X 400).

Fig. (7): Liver section of hydatid cyst infected sheep liver showing necrotic area around the parenchyma of the liver (arrows). (H/E X 200).

Fig. (8): Liver section of hydatid cyst infected sheep liver showing dilated central vein (D), infiltration of eosinophiles (E) and disintegration in the epithelial cells of the bile duct. (H/E X 200). 

التأثير ات النسيجية على كبدِ الخِر افِ نتيجة الإصـابة بالأكياس المائية

\section{ن تبيل زكى زاهد}

قسم العلوم البيولوجيةـ كلية العلوم- جامعة الملك عبد العزيز - المملكة العربية السعودية

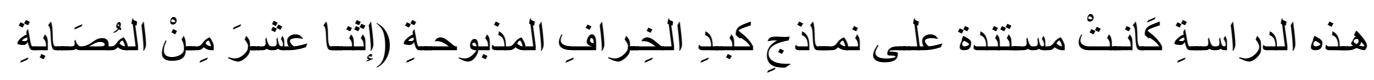
وأربعة مِنْ غير المُصابةِ) جُمِعتْ مِنْ المسالخ المركزية بالمملكة العربية السعودية. هذه النماذج تم فحصها لمعرفة وجود الأكياس المائية وبعد ذلك فَحصتُ نسيجياً للتعرفِ على التغييراتِ النسيجية المرضية. و قد أوضحت النَائج أن العدوى بالأكياس المائية تسبيت فى ارتفاع ذو دلالة إحصائية (بي

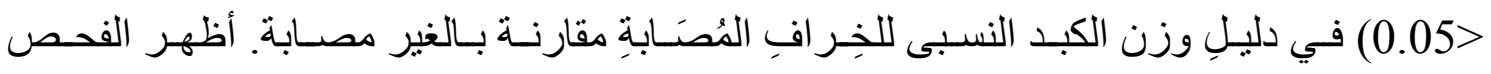
النسيجى لكبد الخر اف المصابة بالأكياس المائية حدوث تغير ات نسيجية مرضية مختلفة تمثّلتُ في ظهور الخلايـا الالتهابيـة وزيـادة الخلايـا الليفيـة والموت الخلوي في المنـاطق المحيطـة بالأكياس المائية. أيضـاً تبين حدوث الفجوات داخل سيتوبلازم الخلايـا الكبديـة وحدوث تمدد فـى الأوعيـة الدموية و التحلل في الخلايا الطلائية لقناةٍ الصفر اءَ. 